\title{
MOŻLIWOŚCI PODNIESIENIA POZIOMU AUTOMATYZACJI W FUNKCJONOWANIU PAŃSTWOWEGO ZASOBU GEODEZYJNEGO I KARTOGRAFICZNEGO W OBLICZU AKTUALNYCH UREGULOWAŃ PRAWNYCH I POSTĘPUJĄCEGO ROZWOJU TECHNOLOGICZNEGO
}

\begin{abstract}
Państwowy zasób geodezyjny i kartograficzny prowadzony jest w Polsce już od kilkudziesięciu lat. Obecna jego forma organizacyjna istnieje od roku 1999, w którym na mocy reformy administracyjnej przywrócono funkcjonowanie powiatów, a zasób danych geodezyjnych przypisanych do powiatów stał się bazą wszelkich opracowań kartograficznych wykorzystywanych w gospodarce, a w szczególności w procesie inwestycyjnym. Metody i środki wykorzystywane do prowadzenia zasobu były zawsze adekwatne do dostępnych środków technicznych. Mapa zasadnicza, jako podstawowy element zasobu, zawsze stanowiła najwierniejszy co do treści, i najdokładniejszy co do lokalizacji model rzeczywistości wykorzystywany przede wszystkim do celów urzędowych, jako pomoc w projektowaniu i realizacji inwestycji. Obecnie obowiązujące przepisy, związane głównie z implementacja dyrektywy INSPIRE, wnoszą wiele zmian w funkcjonowaniu zasobu. Nie zawsze są to jednak zmiany korzystne. W artykule autor przedstawia swoje spostrzeżenia dotyczące problemów w automatyzacji prowadzenia zasobu na bazie wieloletniego doświadczenia $\mathrm{w}$ przedmiotowym temacie oraz stara się przedstawić rozwiązania zidentyfikowanych problemów w zgodzie z osiągnięciami techniki, wiedzą profesjonalna i poszanowaniem prawa. Widoczne problemy to głównie niefortunne rozdzielenie treści mapy zasadniczej na 6 baz specjalistycznych, ale również m.in. niejasne i niespójne zapisy w prawie, brak przygotowania powiatów do korzystania z płatności internetowych czy niezrozumienie istoty dokumentu elektronicznego.
\end{abstract}

Słowa kluczowe: dane przestrzenne, mapa zasadnicza, Infrastruktura Informacji Przestrzennej, IIP

\footnotetext{
${ }^{1}$ Autor do korespondencji: Waldemar Izdebski, Politechnika Warszawska, Wydział Geodezji i Kartografii, pl. Politechniki 1, 00-661 Warszawa, tel. 22-234-7751, email: w.izdebski@gik.pw.edu.pl
} 


\section{Wprowadzenie}

Automatyzacja obsługi zasobu geodezyjnego i kartograficznego była przedmiotem zainteresowania środowiska geodezyjnego od chwili powstania pierwszych komputerów. Szczególnie dużo nowego w tym zakresie wniósł rozwój Internetu, który pozwolił na dostęp do danych zasobu bez fizycznej obecności geodety w ośrodku dokumentacji geodezyjnej i kartograficznej. Przez kilka ostatnich lat rozwijano technologie z tym związane i widać już było odczuwalny postęp. Jednak ostatnie nowelizacje prawa geodezyjnego i kartograficznego spowodowały wiele perturbacji w ewolucyjnie postępującej automatyzacji funkcjonowania zasobu.

Najważniejsze problemy dotyczą wprowadzenia konieczności dokonywania opłat przed otrzymaniem materiałów i wydawania licencji na wykorzystanie materiałów zasobu. Innym istotnym problemem jest też fakt, że nowelizacja ustawy Prawo Geodezyjne i Kartograficzne (PGiK) zmieniła definicję mapy zasadniczej, czyli czegoś, co przez lata było podstawowym elementem zasobu geodezyjnego i kartograficznego. Teraz mapę zasadniczą definiuje się jako standardowe opracowanie kartograficzne tworzone na podstawie odpowiednich zbiorów danych wymienionych $\mathrm{w}$ art. 4 ust. 1a i ust. $1 \mathrm{~b}$ cytowanej ustawy. $\mathrm{Z}$ analizy aktualnych przepisów wynika, że obecna treść mapy zasadniczej składa się z 278 obiektów [8] pochodzących z sześciu rejestrów publicznych:

EGiB - ewidencja gruntów i budynków.

GESUT - geodezyjna ewidencja uzbrojenia terenu.

PRG - państwowy rejestr granic.

PRPOG - państwowy rejestr podstawowej osnowy geodezyjnej.

BDOT500 - baza danych obiektów topograficznych 1:500.

BDSOG - baza danych szczegółowych osnów geodezyjnych.

W nowelizacji w 2010r., przewidziano wprawdzie okres przejściowy do 31 grudnia 2013r. na wprowadzenie stosownych zmian (art. 53b), ale dotrzymanie tego terminu było niemożliwe i zapis o nowej mapie zasadniczej pozostawał martwy. Chcąc wyeliminować problematyczny zapis ustawodawca, przy okazji nowelizacji ustawy PGiK w 2014r., przesunął ostateczny termin wprowadzenia odpowiednich baz do 31 grudnia 2016r., ale dotrzymanie nowego terminu bez działań wspierających jest również niemożliwe i należy go traktować jedynie w kategoriach życzeniowych. Zupełnie inną sprawą jest pytanie o celowość rozbicia mapy zasadniczej na wiele baz źródłowych. Co przez to zyskujemy, a co tracimy?

Ratując sytuację, w nowelizacji 2014r., ustawodawca wprowadził także optymistyczny zapis, że do czasu utworzenia właściwych baz, zamiast mapy papierowej będzie stosowana jej postać rastrowa, systematycznie uzupełniana danymi wektorowymi. Problem się jednak nie rozwiązał, bo nie można postaci rastrowej wprowadzić z dnia na dzień. Tak więc mapa papierowa jak była, tak pozostała nadal. Taki stan powoduje sytuacje konfliktowe, bo wykonawcy prac 
geodezyjnych, coraz częściej, nie chcą aktualizować mapy tradycyjnej, powołują się na zapisy ustawy PGiK, zgodnie z którym taka mapa mogła funkcjonować tylko do 31 grudnia 2013r. I oczywiście sądy przyznają im rację, natomiast nie przekłada się to niestety na szybsze powstawanie map numerycznych.

W kwestii mapy zasadniczej, prowadzonej dotychczas w postaci numerycznej aktualne zapisy określają, że można taką formę pozostawić, ale jedynie do końca 2016 roku, a od 1 stycznia 2017r. wszystko już powinno być prowadzone w wymienionych w ustawie PGiK bazach danych.

$\mathrm{W}$ temacie przytoczonych problemów powiedziano już wiele [3], [6], [7], ale trudności wciąż się utrzymują i tylko ich wyraźne przedstawienie i przeciwdziałanie może przynieść pozytywne efekty. W niniejszym referacie skoncentrujemy się głównie na problemach automatyzacji zasobu i propozycjach takich rozwiązań, które będą wykorzystywały osiągnięcia techniki i wiedzy profesjonalnej w połączeniu z poszanowaniem uregulowań prawnych.

\section{Istota automatyzacji prowadzenia zasobu}

W powszechnym rozumieniu Państwowy Zasób Geodezyjny i Kartograficzny składa się z wyników pomiarów zgromadzonych w operatach technicznych i powstałych na ich bazie opracowań kartograficznych i rejestrów, najczęściej mających już postać numeryczną. Jednym z bardzo istotnych elementów zasobu geodezyjnego i kartograficznego jest mapa zasadnicza [1], będąca najdokładniejszym i najbardziej szczegółowym opracowaniem kartograficznym otaczającej nas rzeczywistości służącym do planowania i realizacji inwestycji oraz ogólnym potrzebom obywateli, gospodarki, obronności czy nauki [5]. Od początku funkcjonowania mapy zasadniczej zdawano sobie sprawę, że nie da się takiego szczegółowego opracowania utrzymać jako całości w stanie ciągłej aktualności. Szukano więc pewnych kompromisów pozwalających gromadzić dane bazowe, które później w wyniku przygotowywania procesu inwestycyjnego byłyby szybko uzupełniane do pełnej aktualności. Tak właśnie powstał zasób geodezyjny i towarzyszące mu prace geodezyjne, których wyniki służą aktualizacji zasobu. Szacuje się, że w Polsce realizowanych jest rocznie ok. 1.000.000 prac geodezyjnych, co oznacza, że skala problemu jest duża i warto zająć się automatyzacją związanych z nimi procesów.

\subsection{Przejawy automatyzacji zasobu}

Przejawy automatyzacji funkcjonowania zasobu geodezyjnego i kartograficznego możemy podzielić na dwie zasadnicze grupy tzn. dla obywateli i dla wykonawców prac geodezyjnych [4]. W przejawach automatyzacji istotnych dla ogółu obywateli wyróżniamy: 
1. Portale mapowe bazujące na danych ośrodków dokumentacji udostępniające podstawowe dane referencyjne jakimi są działki i budynki, czyli najogólniej mówiąc dane geometryczne ewidencji gruntów i budynków.

2. Umożliwienie obywatelom zakup mapy zasadniczej $\mathrm{z}$ wykorzystaniem Internetu.

Wśród przejawów automatyzacji istotnych dla wykonawców prac geodezyjnych należy wymienić:

1. Udostępnienie wykonawcom prac geodezyjnych funkcjonalności umożliwiających zgłoszenia pracy geodezyjnej przez Internet.

2. Automatyzacja procesu przygotowania i udostępnienia materiałów dla wykonawców prac geodezyjnych.

3. Udostępnienie nowoczesnych form komunikacji geodety z ośrodkiem dokumentacji podczas realizacji pracy geodezyjnej.

4. Usprawnienia przy kontroli (weryfikacji opracowań).

5. Przyjęcie operatu do zasobu, a w szczególności przyjęcie operatu elektronicznego.

\section{Problemy związane $z$ automatyzacją prowadzeniem zasobu}

Oprócz zasadniczego problemu technicznego, dotyczącego rozdzielenia treści mapy zasadniczej na 6 baz źródłowych [8] należy zwrócić uwagę na kilka problemów organizacyjno-prawnych, które nie sprzyjają automatyzacji prowadzenia zasobu geodezyjnego i kartograficznego i ogólnej automatyzacji ośrodków geodezyjnych i kartograficznych. Problemy te zostaną omówione w kolejnych podrozdziałach.

\subsection{Uciążliwe i niespójne przepisy dotyczące obsługi prac geodezyjnych}

Na podstawie przeprowadzonej analizy funkcjonowania ośrodków dokumentacji oraz licznych rozmów z przedstawicielami powiatów należy stwierdzić, że dużym hamulcem automatyzacji jest obecny zapis art. 12 ust. 3 ustawy PGiK: "Organ, który otrzymat zgloszenie prac geodezyjnych lub prac kartograficznych, w terminie 10 dni roboczych uzgadnia z wykonawca listę materiatów zasobu niezbędnych lub przydatnych do wykonania zgłoszonych prac $i$ udostępnia ich kopie za optata, o której mowa w art. 40a ust. 1". Często interpretacja tego zapisu jest taka, że wymaga się osobistej wizyty geodety zgłaszającego pracę geodezyjną w odpowiednim ośrodku dokumentacji i złożenie stosownego podpisu. Pomijając zamierzone intencje ustawodawcy, warto pamiętać, że jego działania nie mogą z natury rzeczy powstrzymywać postępu technicznego, a więc oprócz standardowo dopuszczonych form uzgodnienia, należy uznać, że ustawodawca dopuszcza również jego nowoczesne formy. Jedną $\mathrm{z}$ takich form jest przedstawienie, geodecie zgłaszającemu pracę internetowo, wykazu możliwych do wykorzystania materiałów. Jeśli więc przedstawiamy w Internecie 
możliwe do wykorzystania materiały i damy możliwość ich wyboru, to można uznać, że wybór geodety przy zgłaszaniu pracy jest spełnieniem zapisów ustawowych i już nic nie stoi na przeszkodzie, aby proces zgłaszania i obsługi prac automatyzować z pełnym poszanowaniem prawa.

Inne problemy natury prawnej związane $\mathrm{z}$ wprowadzeniem licencji na materiały zasobu, dokumenty obliczenia opłaty i zgłoszenia uzupełniające nie wymagają już problemów interpretacyjnych, a jedynie działań technicznych, więc ich uciążliwość jest eliminowana przez stosowanie nowoczesnych rozwiązań technicznych. Nie oznacza to jednak rezygnacji z krytycznej oceny wprowadzenia takiego systemu opłat i związanych $\mathrm{z}$ nim licencji na wykorzystanie materiałów zasobu. $Z$ zawodowego punktu widzenia trudno jest bowiem pogodzić się z sytuacją kiedy geodeta chcąc profesjonalnie i najlepiej dla PODGiK wykonać prace geodezyjną musi płacić za dostęp do operatów archiwalnych. Jest to zupełnie nielogiczne, podobnie zresztą jak w przypadku osnowy. Nasuwa się natychmiast wniosek, że jeśli już coś należało zmienić to można było uzależnić opłatę od obszaru zgłoszenia, a korzystanie ze wszystkich operatów i osnowy pozostawić bez dodatkowych opłat. Postępowanie takie uprościłoby znacznie proces pobierania opłat i byłoby rozwiązaniem nieobciążającym geodetów opłatami za korzystanie z materiałów archiwalnych.

$\mathrm{Z}$ drobnych aczkolwiek istotnych dla automatyzacji problemów należy zwrócić uwagę, że w przepisach prawnych nie zdefiniowano w sposób jednoznaczny wyglądu obszaru zgłoszonej pracy geodezyjnej. Brak takich uregulowań prowadzi czasami do anomalii utrudniających proces aktualizacji zasobu nie mówiąc już o jego automatyzacji. Zaobserwowany problem w tym względzie związany jest z kształtem obszaru pracy geodezyjnej, który niektórzy geodeci na swój użytek potrafią bardzo skomplikować. Typowym przykładem jest bardzo złożony kształt zgłoszonych prac geodezyjnych obejmujący np. wszystkie miejsca w gminie gdzie wykonawca ma dokonać opracowania. Wykonawca czyni to dlatego, że może zaoszczędzić na opłatach, ale w gruncie rzeczy sprawa się komplikuje przez rozciągnięcie pracy w przestrzeni i czasie, co nie jest korzystne ani dla geodety ani dla ośrodka.

Na podstawie obecnych doświadczeń należy stwierdzić, że konieczne jest uszczegółowienie tego tematu, aby nie można było zgłaszać pracy jako multipoligonu, gdyż generuje to szereg problemów i nie sprzyja automatyzacji prac. W przypadku prac samodzielnych sprawa jest prosta, gdyż każde zgłoszenie ma swój identyfikator i jest niezależne od innych części, a wiec może być w dowolnym czasie przekazane do ośrodka dokumentacji, bez oczekiwania na skończenie całości obszaru. 

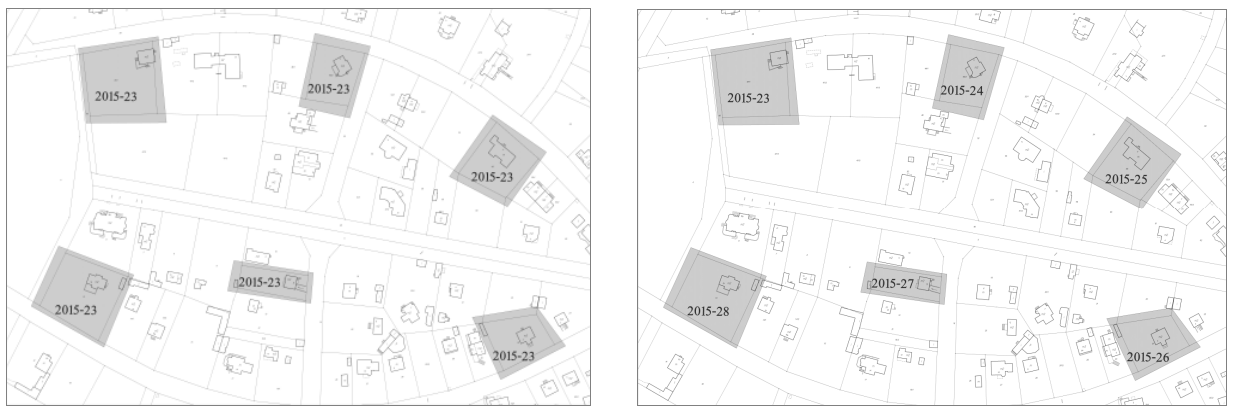

Rys. 1. Zakres pracy geodezyjnej określony jako multipoligon oraz ten sam zakres rozbity na pojedyncze prace geodezyjne

Fig. 1. The range of a geodetic work defined as multipolygon and the same range divided into individual works

Dodatkowo istnieje również problem związany z brakiem wymogu określenia terminu zakończenia pracy geodezyjnej, co powoduje w wielu przypadkach podawanie terminu bardzo odległego np. 2030r. Takie działanie ma mieć na celu uzyskania drobnych oszczędności finansowych wynikających z możliwości operowania zgłoszeniem uzupełniającym do pracy trwającej. Oczywiście nie dotyczy to wszystkich wykonawców, bo akurat większość stara się prace zrealizować szybko, a materiały przekazać do ośrodka dokumentacji, ponieważ klauzula, że operat został przyjęty do zasobu, w wielu przypadkach jest dla zamawiającego konieczna do realizacji czynności urzędowych. Uwaga dotyczy takich wykonawców, którzy taką lukę w prawie bezwzględnie wykorzystują dla własnych korzyści, komplikując przy tym pracę ośrodków dokumentacji.

\subsection{Mało spopularyzowane platności internetowe}

Jedną z najistotniejszych zmian dotyczących procedury zgłaszania prac geodezyjnych wprowadzonych przez nowelizację z 2014 roku jest to, że materiały do pracy geodezyjnej można wydać dopiero po dokonaniu stosownej opłaty. Nawet jeśli niektóre powiaty miały funkcjonującą technologię internetowego zgłaszania prac geodezyjnych, to $\mathrm{w}$ wielu $\mathrm{z}$ nich pojawił się jednak zasadniczy problem, związany z brakiem możliwości pobierania opłat drogą internetową. W dniu 12 lipca 2014r. tylko trzy ośrodki dokumentacji posiadały umowy z firmami obsługującymi płatności internetowe, a więc były gotowe do wdrożenia nowych przepisów. We wszystkich przypadkach były to ośrodki dokumentacji funkcjonujące $\mathrm{w}$ technologii iGeoMap/ePODGiK. W pozostałych ośrodkach trzeba było dopiero podpisać stosowne umowy, co okazało się być procesem długotrwałym i dosyć trudnym. Obecnie na rynku dominują dwie firmy oferujące usługi płatności internetowych tj.: PayU S.A. i KIR S.A. 
Najistotniejszą różnicą w funkcjonowaniu obu serwisów jest obieg środków finansowych. W serwisie PayU wpłata wpływa najpierw na konto bankowe firmy PayU S.A. skąd PODGiK w dowolnym terminie może przelewać środki na swoje konto bankowe. W serwisie PayByNet firmy KIR S.A. środki wpływają natomiast bezpośrednio na konto PODGiK. Druga różnica dotyczy sposobu pobierania prowizji. W serwisie PayU prowizję za usługi płaci przeważnie PODGiK w ustalonych terminach rozliczeniowych, natomiast w serwisie PayByNet prowizja jest przerzucana na osobę opłacającą. Obciążanie osoby opłacającej prowizją budzi wiele wątpliwości i może w przyszłości powodować różne problemy, bo użytkownik mając zagwarantowaną prawem wysokość opłaty jest zmuszany do ponoszenia dodatkowych kosztów. Ostatnią ważną różnicą jest liczba banków dostępnych w obu serwisach. W serwisie PayU jest ich znacznie więcej ( 20 banków) niż w PayByNet ( 8 banków). Jeśli brakuje banku na liście, w przypadku serwisu PayU, możliwe jest wykorzystanie tzw. ścieżki przelewu bankowego czyli wydrukowania przelewu i identyfikatorem transakcji i opłacenia go w sposób tradycyjny. Wpływające na konto bankowe PayU środki automatycznie uruchamiają dalsze procesy przetwarzania pracy. W przypadku PayByNet, gdzie wpłaty trafiają bezpośrednio na konto bankowe PODGiK, geodeta może dokonać wpłaty tradycyjnej, ale nie będzie to skutkowało automatyczną zmianą statusu pracy. Aby tak się stało, pracownik PODGiK po sprawdzeniu, czy środki za daną pracę znalazły się na koncie bankowym, musi ręcznie zmienić status pracy, kwalifikując ją tym samym do dalszego przetwarzania.

Jak widać każdy z przedstawionych serwisów posiada swoje plusy i minusy. Obecnie w 15 funkcjonujących na nowych zasadach wdrożeniach iGeoMap/ePODGiK przewagę 11:4 ma serwis PayU. Niepokojąca jest jednak informacja uzyskana od operatorów płatności internetowych, że ogólnie w Polsce tylko ok. 20 ośrodków dokumentacji uruchomiło u siebie płatności internetowe, a bez tego, jak wiadomo, nie będą w stanie automatyzować obsługi zasobu.

\subsection{Problem operatu elektronicznego}

W standardowym funkcjonowaniu Ośrodków Dokumentacji Geodezyjnej i Kartograficznej operat techniczny związany z wykonaną pracą był dostarczany w postaci tradycyjnych dokumentów papierowych. Naturalną konsekwencją postępu technicznego w nowoczesnych ośrodkach dokumentacji było natychmiastowe skanowanie tego operatu, aby umożliwić automatyzację zarządzania zasobem, udostępniać geodetom lub publikować w Internecie [2]. Najefektywniejszym i najpowszechniejszą formą przechowywania zeskanowanych operatów są pliki w formacie PDF, który to format stał się światowym standardem dla dokumentów elektronicznych.

Wykonawcy geodezyjni także bardzo chętnie korzystają z postępu technicznego i coraz częściej operaty geodezyjne opracowują w całości w postaci elektronicznej i drukują je na papierze jedynie w celu ich przekazania do ośrod- 
ka dokumentacji geodezyjnej i kartograficznej. Aby więc w ośrodku dokumentacji nie zachodziła konieczność skanowania należy opracować taką technologię, która ją wyeliminuje. Prekursorem w rozwiązaniu problemu jest technologia iGeoMap/ePODGiK, w której od początku kwietnia 2015r. uruchomiono możliwość przyjmowania operatu elektronicznego zapisanego w pliku PDF. Operat jest podpisywany elektronicznie w trakcie przesyłania do ośrodka, a następnie podlega weryfikacji przez inspektorów ośrodka dokumentacji. Negatywny wynik weryfikacji skutkuje zwrotem operatu, a pozytywny jego przyjęciem do zasobu nadanie identyfikatora i automatycznym opublikowaniem w Internecie, co daje natychmiast możliwość wykorzystania operatu w innych pracach geodezyjnych.
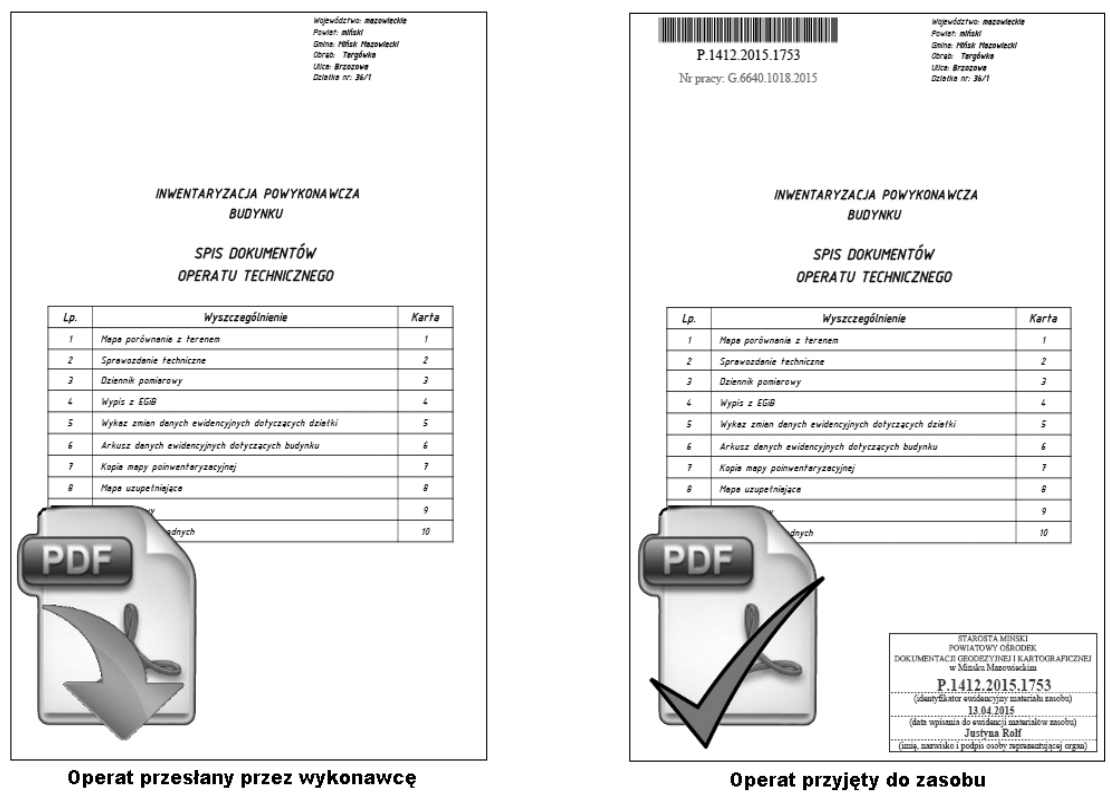

Rys. 2. Ilustracja operatu przesłanego przez wykonawcę i operatu przyjęty do zasobu

Fig. 2. Illustration of a survey document sent by the contractor and the document accepted into resource

Pierwszym wdrożeniem operatu elektronicznego był Powiatowy Ośrodek Dokumentacji Geodezyjnej i Kartograficznej w Mińsku Mazowieckim, gdzie od początku kwietnia 2015r. funkcjonalność udostępniono już kilkudziesięciu wykonawcom geodezyjnym i przyjęto w ten sposób ponad 400 operatów. Ilustrację wzrostu popularności operatu elektronicznego w PODGiK Mińsk Mazowiecki przedstawiono na rys. 3, z którego wyraźnie wynika, że za kilka miesięcy będzie to dominująca forma przekazywania operatów. 


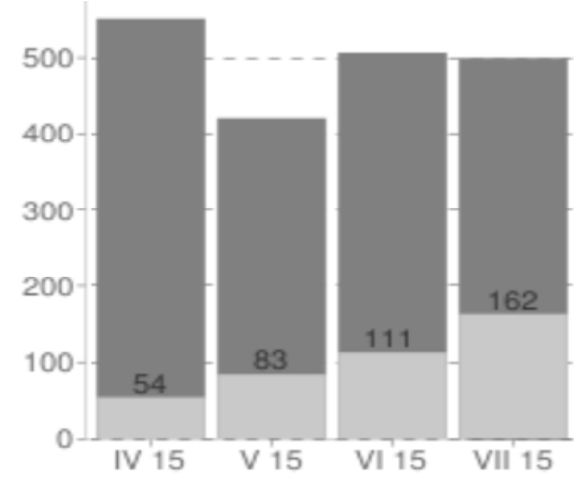

Rys. 3. Wzrost popularności operatu elektronicznego w PODGIK Mińsk Mazowiecki

Fig. 3. The increase in popularity of electronic survey document in PODGiK Minsk Mazowiecki

Przedstawione informacje o operacie elektronicznym mają charakter ogólny, gdyż w szczegółach rozwiązywanych jest jeszcze wiele innych problemów związanych chociażby z operatami mieszanymi tzn. zawierającymi dane papierowe i numeryczne oraz z poprawkami do operatów, które mają miejsce już po ich przyjęciu do zasobu, a tym samym opublikowaniu w Internecie. Zagadnienia te nie są aż tak istotne z punktu widzenia istoty tematu i są tutaj jedynie sygnalizowane.

Zasadniczy problem jaki pojawia się przy operatach dotyczy interpretacji pojęcia "dokument elektroniczny". Automatyzacja, którą przedstawiono jest możliwa jedynie przy układzie gdzie operat jest traktowany jako jeden plik PDF. W przypadku interpretowania pojedynczych dokumentów operatu jako odrębnych dokumentów elektronicznych automatyzacja staje się bardziej skomplikowana i trudno powiedzieć czy logiczna, bo czy wyobrażamy sobie zakup książki w postaci pojedynczych kartek, czy nawet rozdziałów?

\section{Podsumowanie i wnioski}

Jak przedstawiono w treści referatu, nowelizacja ustawy PGiK wprowadziła szereg perturbacji w prowadzeniu zasobu, ale nie można uznać, że w związku z tym nie da się niczego zrobić. Możliwość postępu nie została zablokowana, a jedynie wymaga nastawionej na postęp interpretacji prawa. Przedstawione przykłady, funkcjonujących rozwiązań automatyzujących prace ośrodków dokumentacji, potwierdzają, że nawet $\mathrm{w}$ trudnych uwarunkowaniach prawnych możliwy jest postęp techniczny. Paradoksalnie krytykowane uregulowania prawne mają też pewne plusy, bo pomijając sensowność pobierania opłat za materiały zasobu przed ich wydaniem, to wprowadzenie do powiatów płatności internetowych korzystnie wpłynie $\mathrm{w}$ najbliższym czasie na rozwój e-administracji. 


\title{
Literatura
}

[1] Instrukcja K-1. 1979. Instrukcja techniczna K-1.

[2] Głębicki P., Izdebski W.: Wybrane aspekty przetwarzania zasobu PODGiK do postaci cyfrowej w powiecie wołomińskim. Magazyn Geoinformacyjny GEODETA, grudzień 2007, str. 24-26.

[3] Izdebski W.: Analiza rozporządzenia w sprawie bazy danych ewidencji sieci uzbrojenia terenu, bazy danych obiektów topograficznych oraz mapy zasadniczej. Magazyn Geoinformacyjny GEODETA, czerwiec 2013, str. 14-18.

[4] Izdebski W.: Koncepcja i wdrożenia technologii GEO-MAP. Oficyna Wydawnicza Politechniki Warszawskiej, Warszawa 2013.

[5] Izdebski W.: Dobre praktyki udziału gmin i powiatów w tworzeniu infrastruktury danych przestrzennych w Polsce. (www.izdebski.edu.pl).

[6] Izdebski W. Internetowe zgłaszanie prac geodezyjnych $\mathrm{w}$ technologii iGeoMap/ePODGiK w świetle nowych regulacji prawnych. Magazyn Geoinformacyjny GEODETA, wrzesień 2014, str. 10-12.

[7] Izdebski W.: Analiza projektów nowych rozporządzeń ws. bazy danych ewidencji sieci uzbrojenia terenu oraz ws. bazy danych obiektów topograficznych i mapy zasadniczej. Magazyn Geoinformacyjny GEODETA, grudzień 2014, str. 10-15.

[8] Bielecka E., Izdebski W.: Od danych do informacji - teoretyczne i praktyczne aspekty funkcjonowania mapy zasadniczej. Roczniki Geomatyki 2014, Wydawnictwo "Wieś Jutra" Sp. z o. o., Tom XII, Zeszyt 2 (64) s. 175-184.

\section{THE POSSIBILITY OF RAISING THE AUTOMATION LEVEL IN THE FUNCTIONING OF NATIONAL ORDNANCE ARCHIVE IN THE EYES OF THE CURRENT LAW REGULATIONS AND THE PROGRESSING TECHNOLOGICAL DEVELOPMENT.}

\begin{abstract}
S u m m a r y
National Ordnance Archive is carried out in Poland for decades. Its present organizational form has existed since 1999, in which under the administrative reform restored the functioning of the counties, and county-level ordnance archives became a base for any cartographic work used in the economy, particularly in the development process. Methods and means used to carry out the resource were always adequate to the available technical means. The main map as the basic element of the resource, has always been the most faithful to the content and the most accurate about the location reality model, primarily used for official purposes as an aid in the design and realization of developments. The current law, mainly related to the implementation of the INSPIRE directive, makes a lot of changes in the functioning of the resource. However, those changes are not always beneficial. In the article the author presents his observations concerning problems in the automation of conducting the resource based on many years of experience in this subject and seeks to provide solutions to identified problems in line with advances in technology, professional knowledge and respect for the law. Visible problems are mostly the unfortunate content separation of the main map into 6 specialized databases, but also, among others, vague and inconsistent provisions of the law, the unpreparedness of counties to use online payments or misunderstanding of the nature of the electronic document.
\end{abstract}


Keywords: spatial data, base map, Spatial Data Infrastructure, SDI

Przestano do redakcji:10.08.2015r.

Przyjęto do druku:1.12.2015

DOI: $10.7862 / \mathrm{rb} .2015 .147$ 